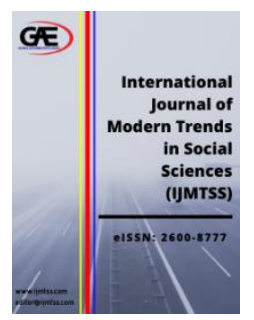

INTERNATIONAL JOURNAL OF
MODERN TRENDS IN
SOCIAL SCIENCES
(IJMTSS)
www.ijmtss.com

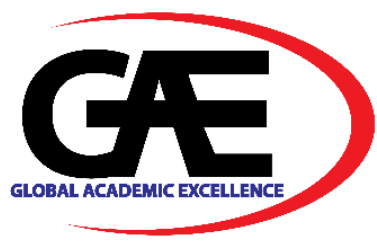

\title{
USING REMOTE SENSING IN STUDY OF EL NIÑO EXTREME DIFFERENCES BETWEEN 1997/1998 AND 2015/2016
}

\author{
Ricky Anak Kemarau ${ }^{1 *}$, Oliver Valentine Eboy $^{2}$ \\ 1 Universiti Malaysia Sabah, Malaysia \\ Email: ricky.geo2005@gmail.com \\ 2 Universiti Malaysia Sabah, Malaysia \\ Email: oliver@ums.edu.my \\ * Corresponding Author
}

\section{Article Info: \\ Article history: \\ Received date: 01.08 .2021 \\ Revised date: 15.08 .2021 \\ Accepted date: 28.08 .2021 \\ Published date: 09.09.2021 \\ To cite this document:}

Kemarau, R. A., \& Eboy, O. V. (2021). Using Remote Sensing in Study of El Niño Extreme Differences Between 1997/1998 and 2015/2016. International Journal of Modern Trends in Social Sciences, 4 (17), 8394.

DOI: $10.35631 /$ IJMTSS.417008

This work is licensed under CC BY 4.0 (1)(1)

\begin{abstract}
:
The years 1997/1998 and 2015/2016 saw the occurrence of El Niño occur among the worst in human history. Until now there is still a lack of research in studying the degree of El Niño's strength impact on climate and weather, especially in the tropic region. The objective of this study is to study the effectiveness of remote sensing technology in identifying the differences between the 1997/1998 and 2015/2016 El Niño events. This study uses six satellite data and temperature data from the Malaysia Meteorology Department (MMD). The first step of remote sensing data will be through pre-processing, converting digital Numbers (DN) to Land Surface Temperature (LST). The results of the study found that there was a change in the pattern of LST columns during the 1997/1998 and 2015/2016 El Niño events. Spatial patterns change based on Oceanic Niño Index (ONI) values. The results of this study are important because of the importance of spatial information to those responsible for preparing measures to overcome and reduce the impact of El Niño on the population. at the developing country level, including Malaysia, there is still a lack of information technology infrastructure in channeling useful information to the community. Through the information, this spatial information provides critical hot spot information that needs more attention.
\end{abstract}

Keywords:

El Niño 1997/1998, El Niño 2015/2016, Remote Sensing, Spatial Pattern

\section{Introduction}

The years 1997/1998 and 2015/2016 saw the strongest El Niño events ever recorded in human history. The occurrence of ENSO is often associated with drought and flood disasters (Kovats, 
Bouma, et al. 2003). The occurrence of ENSO consists of three phases of ENSO known as El Niño (warm tropical Pacific SST), La Niña (cold tropical SST), and Neutral (not El Niño or La Niña) (Chen, 2002). Every incident has different characters (Trenberth and Stepaniak 2001). The following are studies that have been conducted studies on the correlation between ENSO and temperature (Mou et al., 2020; Tavakol et al., 2020; Rane et al., 2019; Fang et al., 2016). In the Malaysian context, the occurrence of ENSO affects climate change in Malaysia (Tangang et al., 2012). but there is still little research to understand the effect of ENSO on temperature (Mou et al., 2020) in an urban area. In addition, a study by Mou e al., (2020), Wall et al., (2020), and Rene e al., (2019) studied the effects of ENSO on climatological and meteorological data. Mou e al., (2020), Tangang et al., (2019), and Dinding et al., (2020) make a study for the whole of Malaysia. Besides that, the knowledge in studying the degree of El Niño's strength to the local weather and climate is still lacking or not yet available, especially the use of satellite remote sensing. Most studies use remote sensing technology in developed countries (Houk et al., 2018; Hawkin et al., 2012; Hawkin et al., 2014; King et al., 2015), namely high latitude areas to study sea surface temperature (SST) and rainfall. Each El Niño event has different intensity, formation process, and duration. This raises interest in comparing the differences between El Niño 1997/1998 and 2015/2016 (Houk et al., 2018). Past studies have stated that the effects of El Niño events vary based on the position of a region. The study area located in the tropics is heavily influenced by the monsoon, Indian Ocean Dipole (IOD), and madden Julian oscillation (MJO). Kemarau and Eboy (2021) and Mou et al., (2020) using temperature from MMD found El Niño affects temperature. However, both studies do not provide spatial information regarding the spatial pattern of LST at the local scale. This study identifies the differences in the effects of El Niño 1997/1998 and 2015/2016 on LST, NDWI, and NDVI. In addition to the relationship between the formation of El Niño and the temperature.

\section{Material and Methodology}

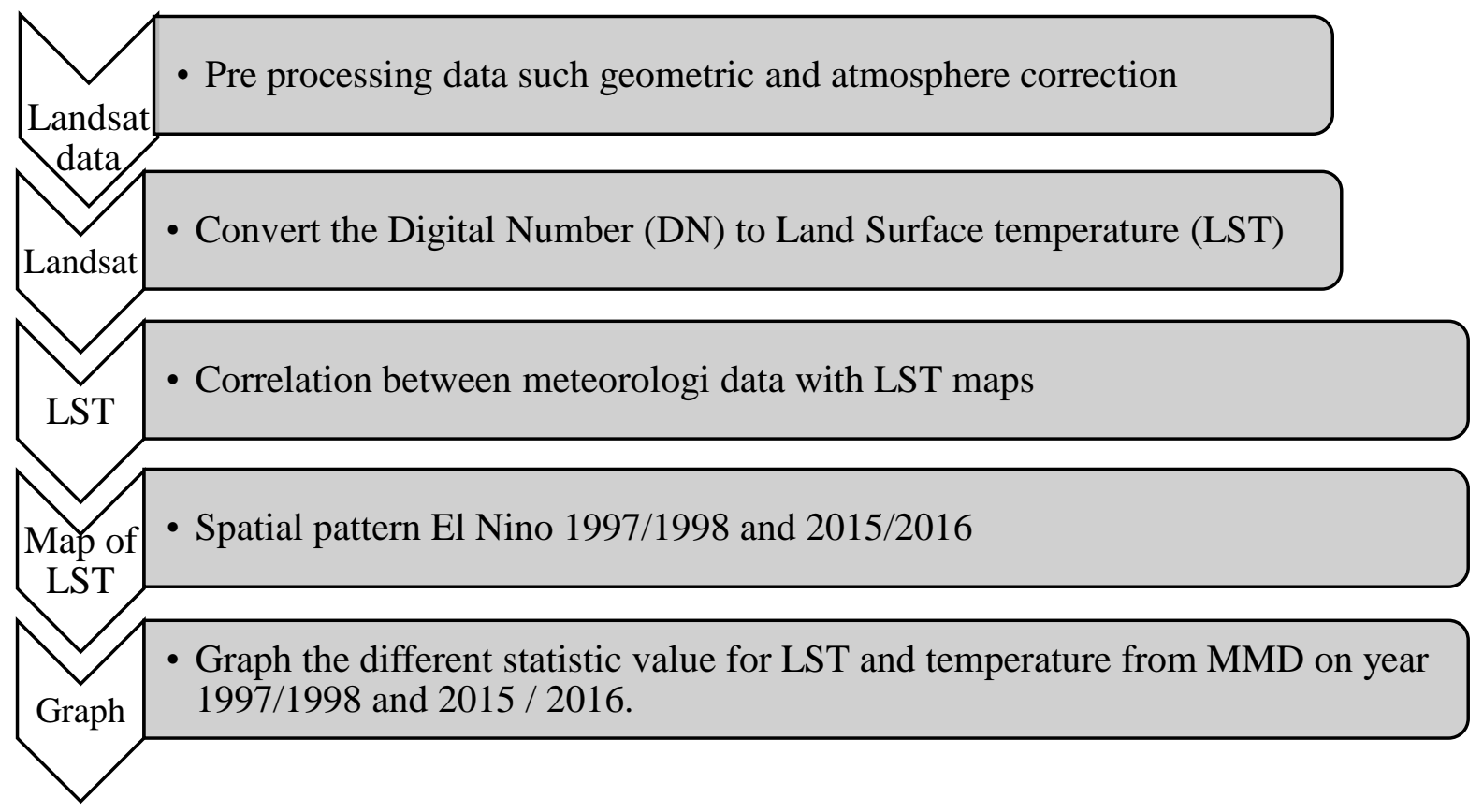

Figure 1: The Graph Above Shows The Flow Chart Of Each Step Carried Out To Achieve The Objectives Of The Study.

Source: Authors

Copyright $\odot$ GLOBAL ACADEMIC EXCELLENCE (M) SDN BHD - All rights reserved 
Every Landsat data must go through pre-process processes such as geometry and atmosphere. Next is the process of converting the value of DN to LST. The Calculations and formulas to convert DN to LST were based on research papers (Ricky and Oliver, 2019). After the LST maps were successfully generated. Correlation analysis should be made between LST with meteorological data from MMD. The pixel coordinate values of LST are the same as those measuring meteorological stations. The next step is to compare the spatial patterns for each LST map for the 1997/1998 and 2015/2016 El Niño years. The next step is to make a comparison between the statistical values of mean, maximal, and minimum of each LST map for 1997/1998 and 2015/2016. To facilitate understanding of the comparison between the events of El Niño 1997/1998 and 2015/2016 statistical data will be presented in graph form.

Daily average temperature data were collected from MMD. Data were collected at Kuching Airport station at location latitude 01 degrees 29 North and longitude 110 degrees 20 East and high above M.S.L 21.7 meters. Data in degrees Celsius. Data used from 1997/1998 and 2015/2016. The monthly mean temperature is calculated from daily temperature, the maximum value for a month, and the minimum value for a month.

The ONI is well established to identify events of El Niño and La Niña (Huang et al., 2016). The ONI index shows the development and intensity of El Niño or La Niña events in the Pacific Ocean. ONI is a three-month Sea Temperature (SST) anomaly in Niño region $3.45^{\circ} \mathrm{N}-5^{\circ} \mathrm{S}$, $\left.120^{\circ}-170^{\circ} \mathrm{W}\right)$. The occurrence of El Niño is defined when the average value of three months at or above $+0.5^{\circ} \mathrm{C}$ anomaly, while the event of La Niña is defined as or under climate Anomaly (NOAA, 2018) $-0.5^{\circ} \mathrm{C}$ (NOAA Forecast Center, 2019). ENSO value grade is classified into 5 classes a Weak (with anomalies 0.5 to 0.9 SST), Medium (1.0 to 1.4), Strong (1.5 to 1.9), and Very Strong ( $\geq 2.0)$ for El Niño events and vice versa for La Niño events. Table 1 shows the ONI values from 1988 to 2019.

Table 1: The Value of ONI For Year 1997/1998 and 2015/2016 Used in This Study

\begin{tabular}{lllllllllllll}
\hline Year & DJF & JFM & FMA & MAM & AMJ & MJJ & JJA & JAS & ASO & SON & OND & NDJ \\
\hline $\mathbf{1 9 9 7}$ & 0.5 & -0.4 & -0.1 & 0.3 & 0.8 & 1.2 & 1.6 & 1.9 & 2.1 & 2.3 & 2.4 & 2.4 \\
$\mathbf{1 9 9 8}$ & 2.2 & 1.9 & 1.4 & 1.0 & 0.5 & -0.1 & -0.8 & -1.1 & -1.3 & -1.4 & -1.5 & -1.6 \\
$\mathbf{2 0 1 5}$ & 0.6 & 0.6 & 0.6 & 0.8 & 1.0 & 1.2 & 1.5 & 1.8 & 2.1 & 2.4 & 2.5 & 2.6 \\
$\mathbf{2 0 1 6}$ & 2.5 & 2.2 & 1.7 & 1.0 & 0.5 & 0.0 & -0.3 & -0.6 & -0.7 & -0.7 & -0.7 & -0.6 \\
\hline
\end{tabular}

Source: NOAA, 2018

Table 2 shows the data used in this study to achieve the objectives. Data selection is only against Landsat data for which there is no cloud coverage. This is because passive remote sensing sensors are unable to penetrate the cloud surface. The selection of data also only involves the year of El Niño which is 1997/1998 and 2015/2016. Table 2 shows the detailed information regarding the Landsat dataset where was applied in this study.

Table 2: The Landsat Dataset was Applied for This Study

\begin{tabular}{ccc}
\hline Sensor & Date Data Acquisition & Data Resolution (Meters) \\
\hline Landsat 5 TM & 18 May 1997 & 100 resolutions resample to 30 \\
Landsat 5 TM & 19 June 1997 & 100 resolutions resample to 30 \\
Landsat 5 TM & 19 April 1998 & 100 resolutions resample to 30 \\
Landsat 7 ETM & 15 June 2015 & 100 resolutions resample to 30 \\
Landsat 7 ETM & 11 October 2015 & 100 resolutions resample to 30 \\
Landsat 7 ETM & 1 April 2016 & 100 resolutions resample to 30 \\
\hline
\end{tabular}


The climate in Kuching is influenced by MJO, ENSO, IOD (Hua et al., 2013), and Monsoon season (Dindang et al., 2013; Yik et al., 2015). In recent years, ENSO phenomena, climate change, and several incidents of heavy rainfall have been reported in Borneo Malaysia including in the study area, namely Kuching (Kemarau and Eboy, 2021). In 2015, the floods left many low-lying areas in Kuching, Sarawak (Kemarau and Eboy, 2021). On the other hand, 2009 was also recognized as the last year for Sarawak when two major rainfall events caused severe floods covering the whole of Sarawak including Kuching (Hamdan et al., 2010). This phenomenon has raised concerns to encourage more research on meteorological data flow analysis to examine whether these changes are statistically significant or significant (Kemarau and Eboy, 2021). In addition, there is still a lack of previous studies examining the effects of El Niño in the tropics specifically the Kuching city area especially on temperature.

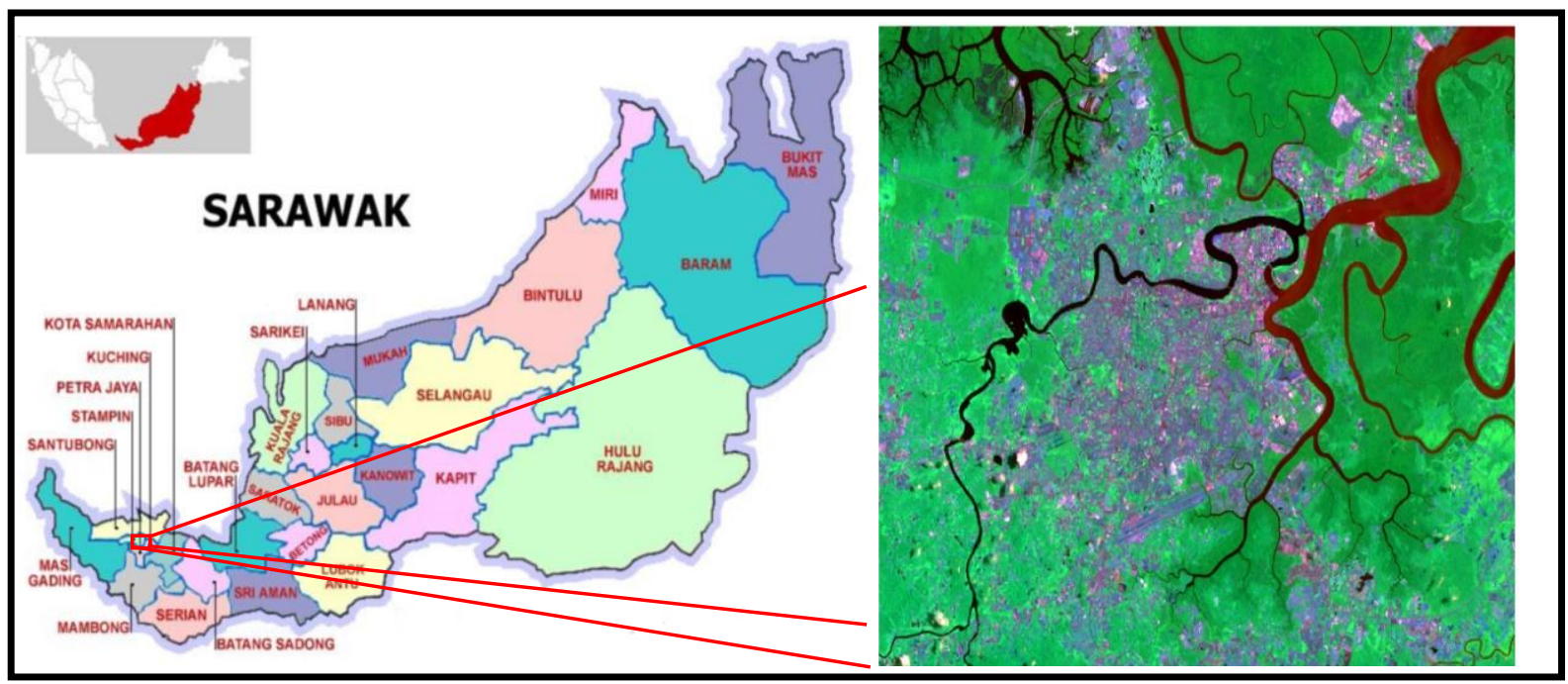

Source: Authors

Figure 2: The Location of The Study

\section{Result and Discussion}

Based on figure 3 can be seen that an increase in the ONI value will cause the local temperature to rise. For example, if the ONI value is 0.6 then the temperature value is 26 degrees Celsius. if the ONI value increases to 2.4 then the temperature value is 28.3 degrees Celsius.

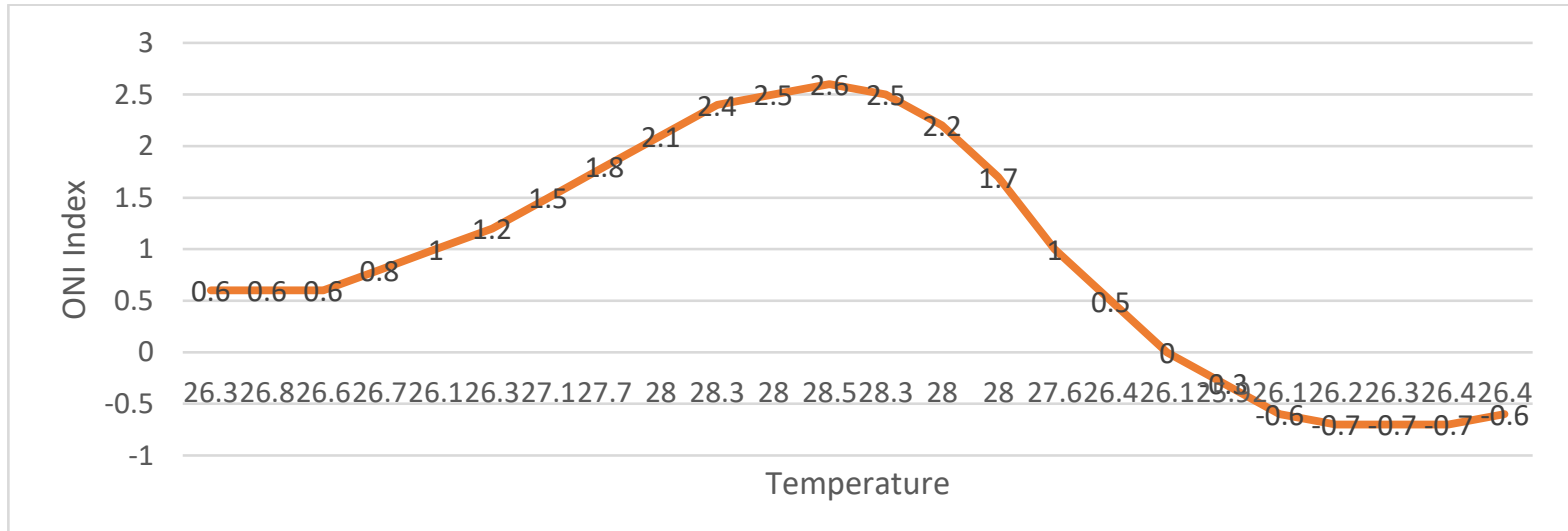

Figure 3: Graph Shows the Relationship Between the ONI Index and The Temperature Source: Authors. 
Based on figure 4 it is found that the relationship between ONI and temperature is at a positive correlation coefficient value of 0.7 . This means that increasing the ONI value will cause the temperature increase and the decrease in ONI will lower the temperature value. Global temperatures are also affected by La Niña and El Niño events due to heat exchange between the atmosphere and the oceans (Turkington e al., 2018; Australian Meteorological Department). In addition, Freychet et al. (2018) also found that the highest meteorological temperature values were recorded during the peak of El Niño in 2016 i.e. during the day compared to during the ONI neutral event. Meteorological temperatures were also recorded highest during El Niño peaks at night compared to neutral ONI night temperatures. This is because building materials that absorb heat during the day will release heat at night (Freychet et al., (2018). Lijie et al., (2018) confirmed that El Niño has caused a temperature rise in Indochina from 0.53 degrees Celsius to 0.60 degrees Celsius at the peak of El Niño.

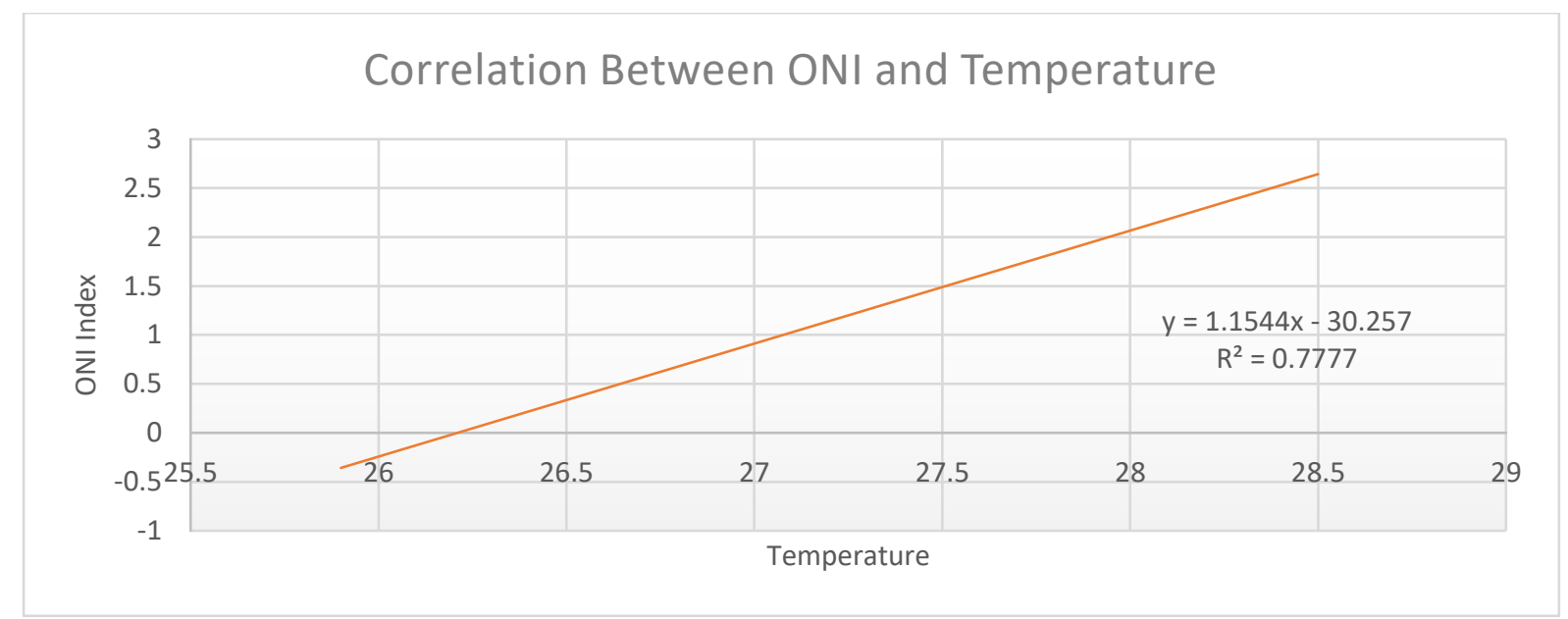

Figure 4: The Correlation Between ONI and The Mean Temperature Every Three Months

Source: Authors

Their study also found that this El Niño incident also weakened the eastern monsoon winds. This statement is also confirmed by Luo and Lau (2018). The occurrence of La Niña and El Niño has the opposite effect on the temperature in Indochina. The study of Lijie et al., (2018) also states that the occurrence of El Niño also causes heat waves to Indochina. This means that the temperature on the surface is higher than normal. This is due to the lack of rainfall in Indochina during El Niño compared to La Niña. The results of this study are like the findings of studies such as Lijie et al., (2018) and Lou and Lau (2018). 


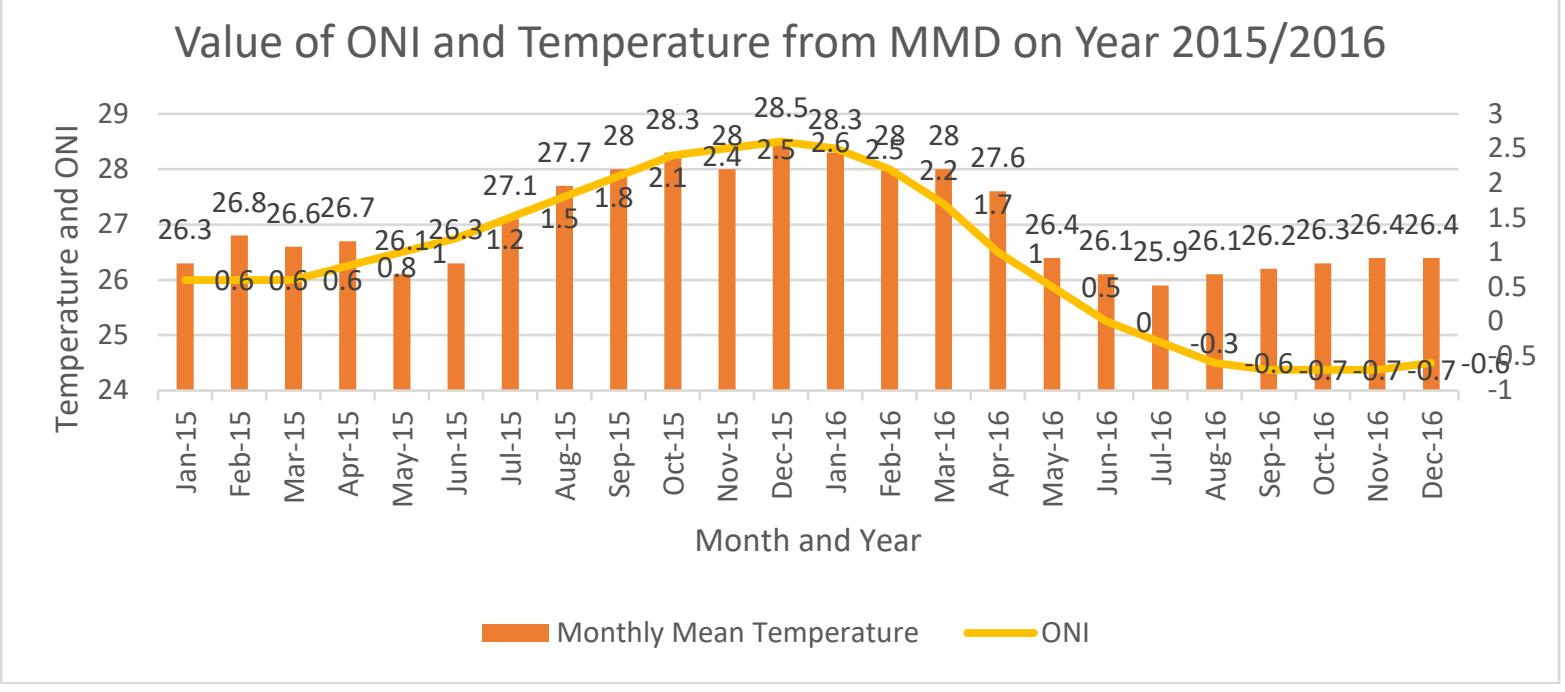

Figure 5: Graph Shows the Value of ONI and Temperature from MMD in The Year 2015/2016

Source: Authors

Based on figure 5, the El Niño incident in 2015/2016 occurred from January 2015 until May 2016. The ONI value increased from April 2015 which is 0.8 where the temperature value is 26 until the maturity of El Niño in December 2015 which is at a value of 2.6 where the temperature value is 28.5. After the peak time in December 2015, the ONI value decreased from January 2016 until July 2016.

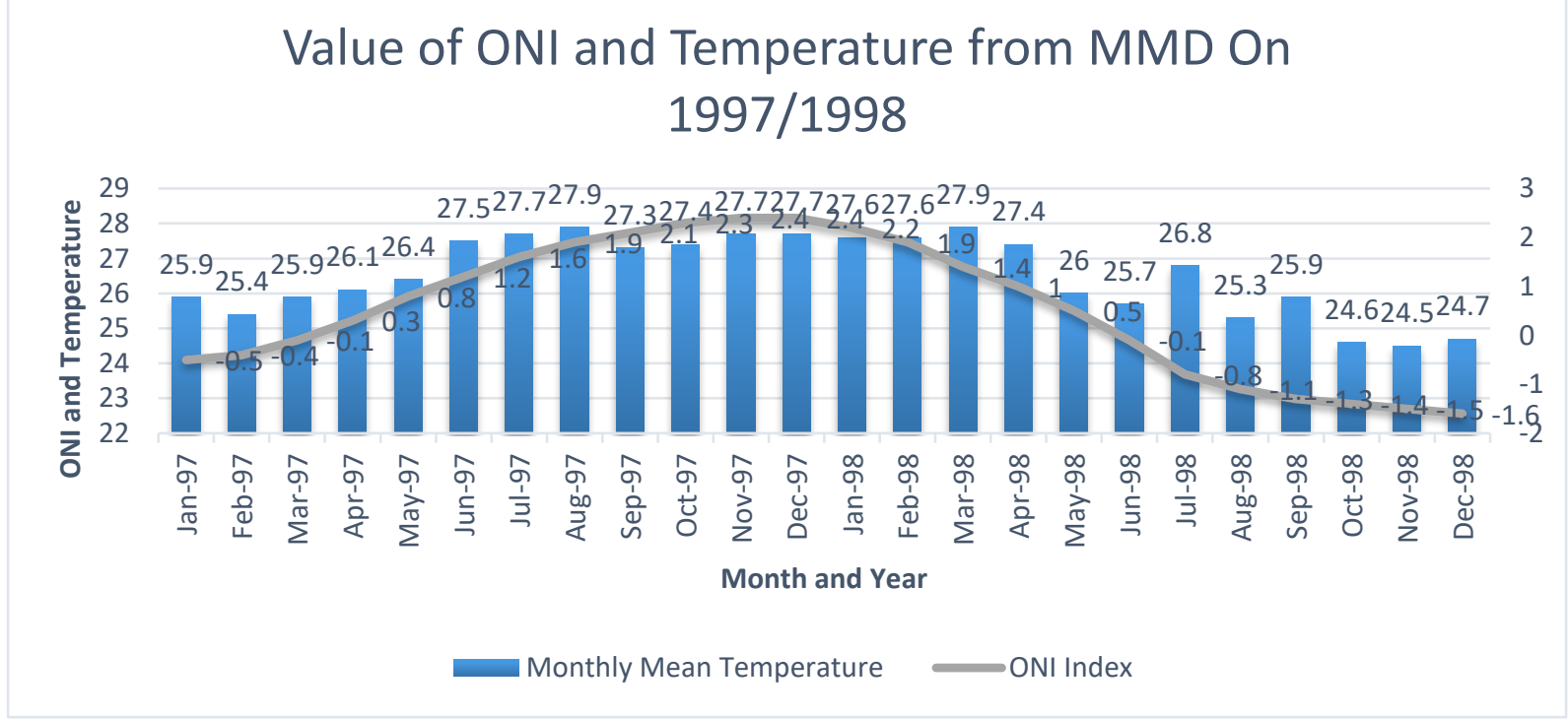

Figure 6: Graph Shows The Value of ONI and Temperature from MMD in The Year $1997 / 1998$

Source: Authors

Based on figure 6 shows the occurrence of El Niño in 1997/1998 starting in May 1997 where the value is ONI 0.8 and temperature 26.4. The ONI value increased for the next month until the peak time in December 1998 where the ONI value was 2.4 and the temperature was 27.2 and decreased to 0.5 in May 1998 and the temperature value was 26. Based on both graphs 
above. The following is a table explaining the differences between the 1997/1998 and 2015/2016 El Niño events. Table 3 shows the difference between El Niño 1997/2018 and $2015 / 2016$

Table 3: The Difference Between El Niño 1997/1998 and 2015/2016

\begin{tabular}{|l|l|l|}
\hline \multirow{2}{*}{ Features } & \multicolumn{2}{c|}{ Year } \\
\cline { 2 - 3 } & El Niño 1997/1998 & EI Niño 2015/2016 \\
\hline Duration & 13 months & 17 months \\
\hline Highest Temperature Value & 27.9 & 28.5 \\
\hline Lowest Temperature Value & 26.4 & 26.3 \\
\hline Highest value ONI & 2.4 & 2.6 \\
\hline Lowest Value ONI & 0.8 & 0.5 \\
\hline $\begin{array}{l}\text { Duration month with value over 1.5 } \\
\text { (Strong) }\end{array}$ & 9 months & 9 months \\
\hline
\end{tabular}

Source: Authors.

Based on table 3 shows El Niño occurred in 2015/2016 longer than El Niño 1997/1998 which is 17 months compared to 13 months El Niño 1997/1998. This means a difference of 4 months longer during the 2015/2016 incident. However, the long period in the month where the ONI value exceeds 1.5 between El Niño is the same 9 months. An ONI value above 1.5 means the degree of El Niño strength is strong. The highest ONI value was recorded in El Niño 2015/2016 which is 2.4 and the highest ONI value in 1997/1998 is 2.4. Next, the highest temperature record was recorded at El Niño 2015/2016 which was 28.5 while El Niño 1997/1998 was 27.9. Houk et al., (2018) stated 2015/2016 o is one of the strongest events ever recorded and has been generally considered to be similar and comparable to another extreme event-the 1997/1998 El Niño. However, this study found the El Niño 2015/2016 difference in duration, higher temperature value, lowest temperature value, and value of higher or lowest ONI. However, the duration month with a value over 1.5 (strong) is similar. That explained the Houk et al., (2018) the El Niño consider similar. Houk et al., (2018) also found that there is a difference in the process of El Niño formation that is the increase of the El Niño Index to maturity. The El Niño index will decline after maturity because of the findings of this study. Kaustubh et al., (2016) state that El Niño in 2015/2016 recorded the highest temperature in the history of El Niño especially in April 2016. For comparison for the study area in February and March, 2016 recorded the highest temperature in El Niño 2016 (Refer to figure 3).

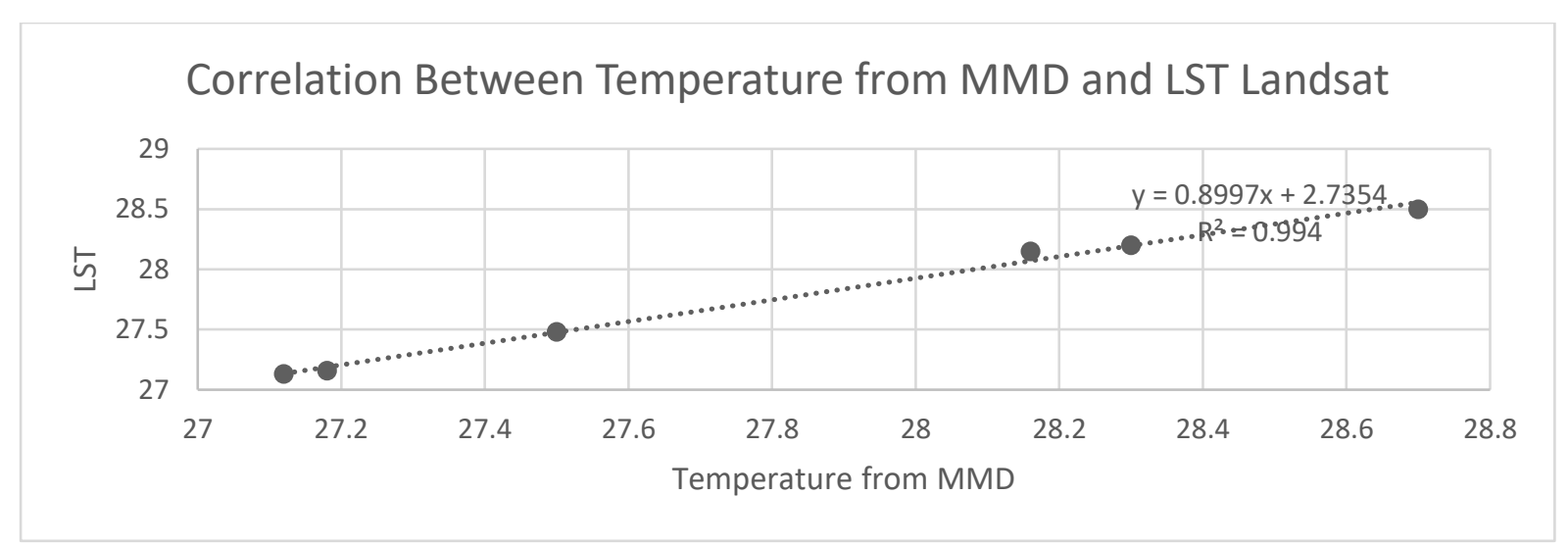

Figure 7: The Correlation Between Temperature From MMD And LST Landsat. Source: Authors 


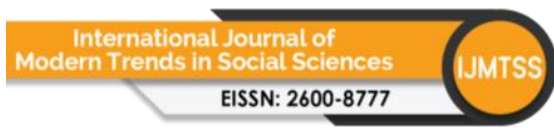

Volume 4 Issue 17 (September 2021) PP. 83-94 DOI 10.35631/IJMTSS.417008

Refer to figure 7 which shows the positive relationship between LST and temperature from MMD which is with a correlation value coefficient of 0.9. The LST value is taken at the same coordinate pixels as the MMD measuring instrument. Test results These results are like the findings of a study by Nusseiba Nour Eldeen et al., (2020). Nusseiiba Nour Eldeen et al., (2020) uses MODIS data and data measured at meteorological stations. The result of their correlation test between LST MODIS temperature and meteorological data is 0.90. In addition, Garfinkel and Butler (2018) also support the findings of Nusseiiba Nour Eldeen et al., (2020). The findings of this study are also supported by Muhamed Hereher (2016) using 273 MODIS images and meteorology in studying the LST time series in the effects of global warming. Their correlation result is between LST MODIS, and meteorological temperature is $84 \mathrm{R}$ values. In addition, Wei Zhou et al., (2019) also used a combination of meteorological data with MODIS data in studying SP changes in the Himalayan region. The results of the study showed a good correlation of $0.90 \mathrm{R}$. The results of their study found that there was a change in SP in the Himalayan area, especially in the capital of Nepal, Kathmandu. Land-use change from natural to urban areas is a major factor causing temperature changes in the Himalayan region. Based on the results obtained by Wei Zhou et al., (2019) proved that there is a good correlation between MODIS LST data and meteorological data.

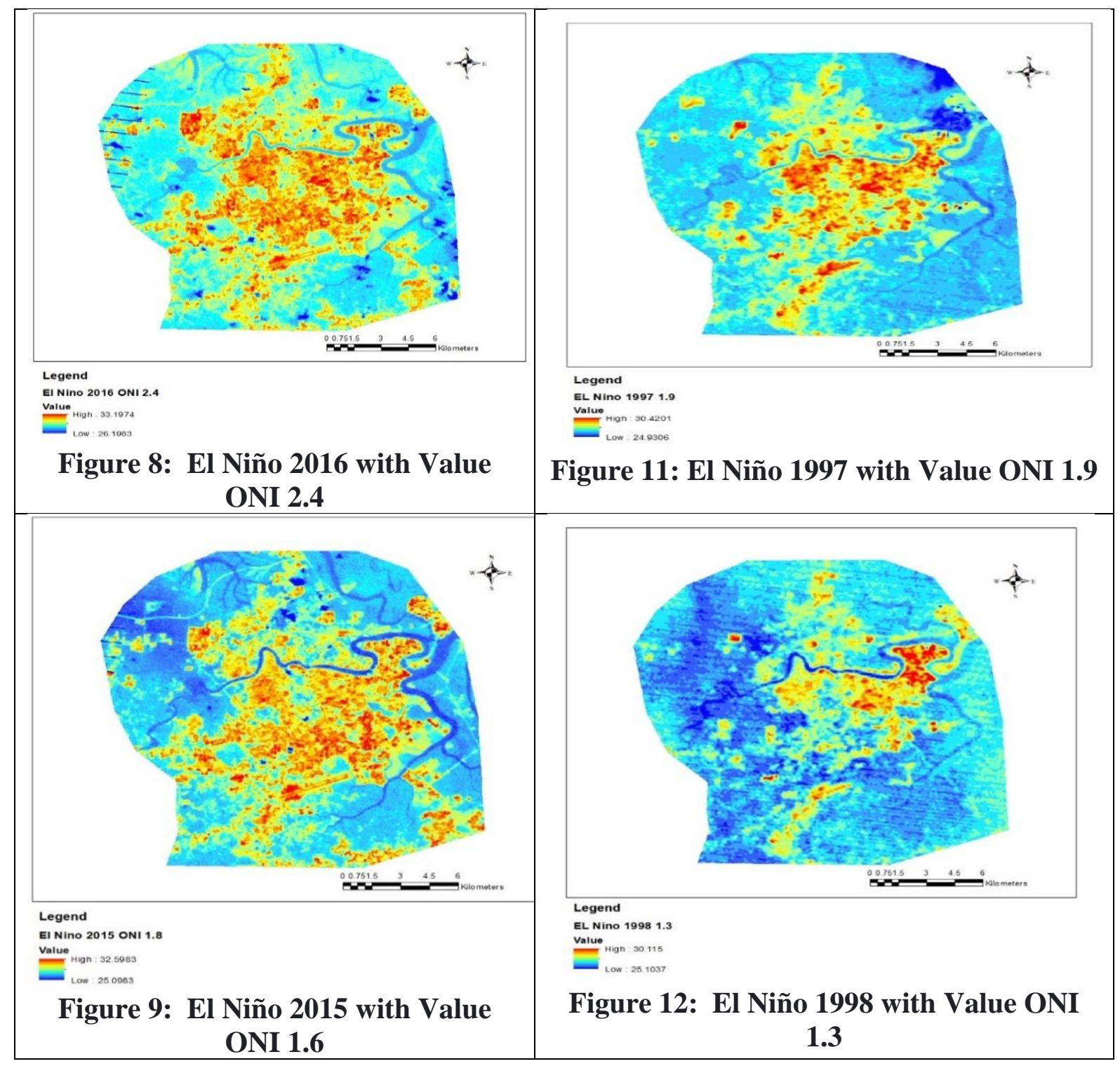

Copyright $\odot$ GLOBAL ACADEMIC EXCELLENCE (M) SDN BHD - All rights reserved 


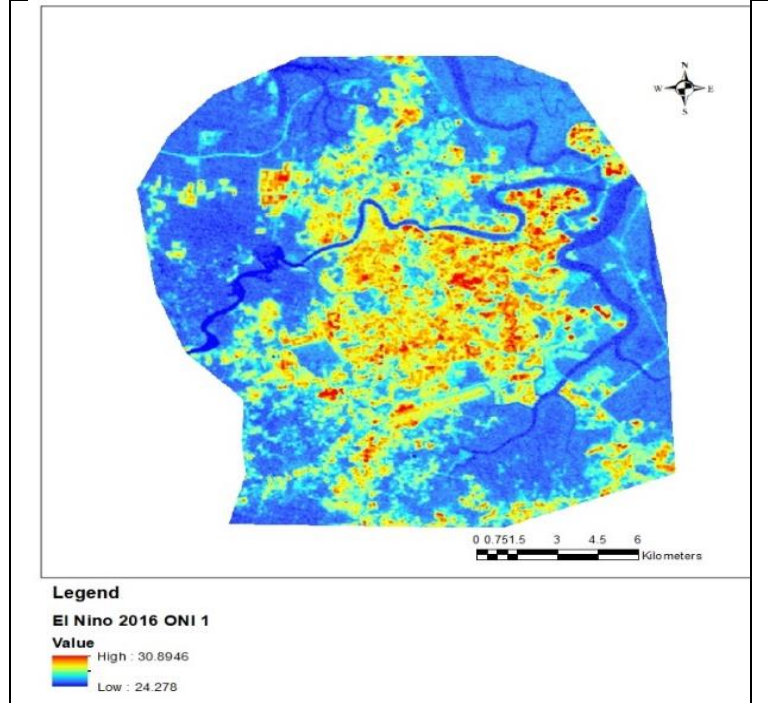

Figure 10: EI Niño 2016 with Value ONI 1

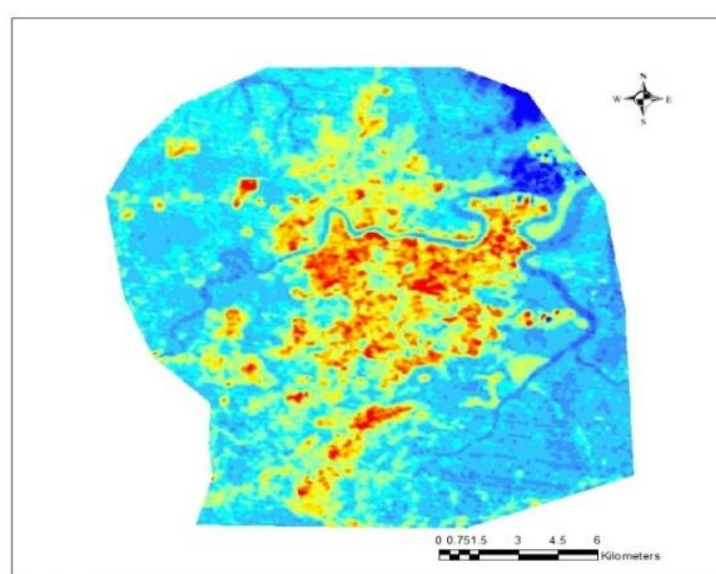

Legend

EL Nino 19971.9

Value High 30.4201

Figure 13: El Niño 1997 with Value ONI

1.9

Figure 14: The Spatial Pattern for LST Between El Niño 2015/2016 (Figure 8,9,10) and El Niño 1997/1998 (Figure 11,12,13)

Source: Authors.

Based on figure 14 shows that there is a change in the pattern of space between El Niño especially the maximum and minimum values. the table describes the LST spatial changes between 1997/1998 and 2015/2016 El Niño.

Table 4: The LST Spatial Changes Between 1997/1998 and 2015/2016 El Niño

\begin{tabular}{|c|c|c|c|c|}
\hline Statistic Value & ONI Value & El Niño 2015/2016 & $\begin{array}{c}\text { ONI } \\
\text { Value }\end{array}$ & El Niño 1997/1998 \\
\hline Maximum & \multirow{3}{*}{2.4} & 33.19 & \multirow{3}{*}{1.9} & 30.42 \\
\hline Minimum & & 26.19 & & 24.93 \\
\hline Mean & & 31.13 & & 29.14 \\
\hline Maximum & \multirow{3}{*}{1.8} & 32.59 & \multirow{3}{*}{1.3} & 30.11 \\
\hline Minimum & & 25.09 & & 25.1 \\
\hline Mean & & 30.87 & & 28.77 \\
\hline Maximum & \multirow{3}{*}{1} & 30.89 & \multirow{3}{*}{1.9} & 30.42 \\
\hline Minimum & & 24.27 & & 24.93 \\
\hline Mean & & 29.14 & & 28.98 \\
\hline
\end{tabular}

Source: Authors.

Based on the table above (Table 4) shows the difference between El Niño 2015/2016 and El Niño 1997/1998 where the mean temperature value for El Niño 2015/2016 is higher than that of El Niño 1997/1998. In addition, the maximum temperature value for El Niño 2015/2016 is also higher compared to the 1997/1998 El Niño temperature value. However, the minimum temperature value indicates depending on the ONI value. For example, the minimum value of temperature in El Niño 1997/1998 at the value of ONI 1.9 compared to the value of minimum temperature in El Niño 2015/2016 at the value of ONI 1. The results of the study found close to the findings of Houk et al., (2018) who found the high-temperature value in 2015/2016 due to warming in the central Pacific Ocean in El Niño 2015/2016 higher than 1997/1998 which is 
3.5 degrees Celsius. This study found that the degree of the El Niño effect depends on the phases of El Niño formation especially the rate of increase and decrease of ONI. Kaustubh et al., (2016) stated that April 2016 saw LST recorded the highest in history. April 2016 was the culmination of the 1997/1998 El Niño. In addition, they state that rising temperatures are also contributed by global warming. The results of this study also agree with the findings of Kaustubh et al., (2016). Despite El Niño's extreme influence the increase in urbanization activities also contributed to the increase in LST. This explains why the mean and maximum LST values are high for El Niño 2015/2016. In addition, Kaustubh et al., (2016) found that in April 2016 it was found to record the highest temperature in the history of El Niño.

\section{Conclusion}

The objective of this study was successfully achieved which is to identify the differences in the effects of the 1997/1998 and 2015/2016 El Niño events. Studies show both the strongest extreme El Niño events recorded (related, 1997/1998 and 2015/2016) were very different in effect on the LST spatial patterns. In addition to LST spatial patterns differ based on ONI values. ONI values play an important role in determining the patterns of LST. In addition, the ONI value plays an important role in the formation of El Niño evolution, and it has an impact on local and global temperatures. The study found that the 1997/1998 events less influenced the values of LST. This is because the influence of global warming influences this decision. Observation of ONI values is very important in predicting the effects of El Niño on the weather.

\section{Acknowledged}

Thanks to NASA and Malaysia Meteorology Department for Data.

\section{Reference}

Abul Quasem Al-Amina And Gazi Mahabubul Alam (2018). The Impact of El-Niño On AgroEconomics in Malaysia And the Surrounding Regions: An Analysis of The Events From 1997-98. Asian J. Earth Sci., 9: 1-8. DOI: 10.3923/ajes.2016.1.8 (2016)

Drosdowsky W, Wheeler MC. (2014) Predicting the Onset of The North Australian Wet Season with The POAMA Dynamical Prediction System. Wea. Forecasting, 29, 150-161. DOI:10.1175/WAF-D-13-00091.1(2014).

Farras F. Nabilah, Y. Prasetyo, and A. Sukmono, (2017). Analisis Pengaruh Fenomena El Niño dan La Niña Terhadap Curah Hujan Tahun 1998-2016 Menggunakan Indicator (Oceanic Niño Index) (Studi Kasus : Provinsi Jawa Barat)," Jurnal Geodesi Undip, vol. 6, no. 4, pp. 402-412, Nov. 2017. [Online]. https://ejournal3.undip.ac.id/index.php/geodesi/article/view/18170 (2017)

Freychet, N., S. Sparrow, S. F. B. Tett, M. J. Mineter, G. C. Hegerl, And D. C. H. Wallom,. (2018). Impacts of Anthropogenic Forcings And El Niño On Chinese Extreme Temperatures. Adv. Atmos. Sci., 35(8), 994-1002, Https://Doi.Org/10.1007/ S00376018-7258-8.(2018).

Hawkins, E. Jin, M.; Dickinson, R.E. (2014). Uncertainties in the timing of unprecedented climates. Nature 511, E3-E5 (2014). doi:10.1038/s41558-020-00957-9.(2014).

Houk, Paek, J.-Y. Yu, and C. Qian, (2017). Why were 2015/2016 and 1997/1998 extreme El Niños different? Geophys. Res. Lett., 44, 1848-1856, doi:10.1002/2016GL071515. (2017)

Hawkins, E. \& Sutton, R.(2012). Time of the emergence of climate signals. Geophys. Res. Lett. 39, L01702 (2012). https://doi.org/10.1029/2011GL050087 (2012) 
Jin, M.; Dickinson, R.E. (2010). Land surface skin temperature climatology: Benefitting from the strengths of satellite observations. Environ. Res. Lett. 2010, 5, 044004. https://iopscience.iop.org/article/10.1088/1748-9326/5/4/044004.(2010)

Luo, M. And Lau, N.-C. (2018). Synoptic Characteristics, Atmospheric Controls, And LongTerm Changes of Heat Waves Over the Indochina Peninsula. Climate Dynamics. Https://Doi.Org/10.1007/S00382-017-4038-6. (2018).

Kaustubh Thirumalai, Pedro N. DiNunzio, Yuko Okumura \& Clara Deser (2016). Extreme temperatures in Southeast Asia caused by El Niño and worsened by global warming. NATURE COMMUNICATIONS. DOI: 10.1038/ncomms15531. (2016).

Kemarau, R., \& Eboy, O. V. (2021). The Impact of El Niño-Southern Oscillation (ENSO) on Temperature: A Case Study in Kuching, Sarawak. Malaysian Journal of Social Sciences $\begin{array}{lllll}\text { and Humanities } & \text { (MJSSH), 6(1), } & 289 & - & 297 .\end{array}$ https://doi.org/https://doi.org/10.47405/mjssh.v6i1.602

Kemarau, R. A., \& Eboy, O. V. (2021). Application of Remote Sensing on El Niño Extreme Effect in Normalized Difference Vegetation Index (NDVI) and Normalized Difference Water Index (NDWI). Malaysian Journal of Applied Sciences, 6(1), 46-56.

King, A. D. (2015). The timing of anthropogenic emergence in simulated climate extremes. Environ. Res. Lett. 10, 094015 (2015). DOI: 10.1088/1748-9326/10/9/094015. (2015).

Mahlstein, I., Hegerl, G. \& Solomon, S. (2012). Emerging local warming signals in observational data. Geophys. Res. Lett. 39, L21711 (2012). doi:10.1029/2012GL053952, (2012).

MMD (Malaysia Meteorological Department) 2020. Summary of Climate. Available at Http://Www.Met.Gov.My/Iklim/Laporanringkasan/Maklumatiklim (Accessed On 19 September 2020).

Mou Leong Tan, Liew Juneng, Fredolin T. Tangang, Jing Xiang Chung, R.B. Radin Firdaus. (2020). Changes in Temperature Extremes and Their Relationship with ENSO in Malaysia from 1985 To 2018 Article In International Journal Of Climatology October 2020. https://doi.org/10.1002/joc.6864. (2020)

Mohamed E. Heather. (2016). Time Series Trends of Land Surface Temperatures In Egypt: A Signal For Global Warming Environ Earth Sci (2016) 75:1218 DOI 10.1007/S12665016-6024-4.(2016)

NOAA (2020). National Centers For Environmental Information, State of The Climate: Global Climate Report for Annual 2019. Available at Https://Www.Ncdc.Noaa.Gov/Sotc/Global/201913. (Accessed On 16 March 2020).

Nussieiba Noureldeen, Kebiao Mao, Zijin Yuan, Xinyi Shen, Tongren Xu, And Zhi Hao Qin, (2020). Analysis of The Spatio Temporal Change in Land Surface Temperature for Long Term Sequence in Africa (2003-2017). Remote Sens. 2020,12,488; Doi 10.3390/Rs 12030488 (2020)

Ricky Anak Kemarau and Oliver Valentine Eboy (2020). Land Coverage Indices and Its Impact on Land Surface Temperature Pattern in Small Medium Sizes, Kota Kinabalu City for The Year 1991, 2011 and 2018, Journal of Built Environment, Technology and Engineering, Vol. 7 (Sept.) ISSN 0128-1003. https://jbete.org/wpcontent/uploads/2020/10/JBETE7_22.pdf. (2019)

René D. Garreaud Juan P. Boisier, Roberto Rondanelli, Aldo Montecinos, Hector H. Sepúlveda Daniel Veloso-Aguila (2019). The Central Chile Mega Drought (20102018): A Climate Dynamics Perspective. International Journal of Climatology, Royal Meteorological Society. https://doi.org/10.1002/joc.6219. (2019) 
Renganathan Giridharana And Rohinton Emmanuel. (2018). The Impact of Urban Compactness, Comfort Strategies, And Energy Consumption on Tropical Urban Heat Island Intensity: A Review. Sustainable Cities and Society 40 (2018) 677-687. https://doi.org/10.1016/j.scs.2018.01.024. (2018)

Suhaila, J. \& Yusop, Z. (2018). Trend Analysis and Change Point Detection of Annual and Seasonal Temperature Series in Peninsular Malaysia. Meteorology and Atmospheric Physics, 130, 565-581. DOI: 10.1007/s00703-017-0537-6. (2018)

Song Yang, Zhenning Li1, Jin-Yi Yu, Xiaoming Hu, Wenjie Dong, and Shan He. (2018). El Niño-Southern Oscillation and Its Impact in the ${ }^{\sim}$ Changing Climate. National Science Review 5: 840-857, 2018 Doi: 10.1093/Nsr/Nwy046 (2018)

Tan, M. L., Samat, N., Chan, N. W., Lee, A. J. \& Li, C.. (2019). Analysis of Precipitation and Temperature Extremes Over the Muda River Basin, Malaysia. Water, 11, 283. https://doi.org/10.3390/w11020283. (2019)

Tang, K. H. D. (2019). Climate Change in Malaysia: Trends, Contributors, Impacts, Mitigation, and Adaptations. Science of The Total Environment, 650, 1858-1871. DOI: 10.1016/j.scitotenv.2018.09.316 (2019)

Tangang, F., Juneng, L., Salim, E., Sei, K. \& Loh, J. Climate Change and Variability Over Malaysia: Gaps In Science And Research Information. Sains Malaysiana, 41, 13551366. http://www.ukm.my/jsm/pdf_files/SM-PDF-41-11 2012/05\%20Fredolin\%20T\%20Tangang.pdf (2012)

Trenberth, K. E. And D. P. Stepaniak. (2001) Indices Of El Niño Evolution." Journal of Climate14(8): 1697-1701.DOI: https://doi.org/10.1175/1520 (2001).

Turkington, T., Timbal, B., \& Rahmat, R. . (2018). The Impact of Global Warming on Sea Surface Temperature Based El Niño Southern Oscillation Monitoring Indices. International Journal of Climatology, 39(2). https://doi.org/10.1002/joc.5864 (2018)

Xie S-P, Hu K and Hafner J. (2009). Indian Ocean Effect on Indowestern Pacific Climate During the Summer Following El Niño. J Clim 2009; 22: 730-47. DOI: 10.1175/2008JCLI2544.1. (2009)

Yu J, Paek H, and Saltzman. (2015). The Early 1990s Change In ENSO-PSA- SAM Relationships and Its Impact on Southern Hemisphere Climate. J Clim 2015; 28: 9393 408. DOI: 10.1175/JCLI-D-15-0335.1. (2015). 